\title{
ПСИХОЛОГІЧНИЙ СУПРОВІД ФОРМУВАННЯ ПРОФЕСІЙНОЇ ІДЕНТИЧНОСТІ В УМОВАХ ЗМІН
}

\author{
ORCID iD: https://orsid.org/0000-0003-4691-9445
}

DOI: 10.33216/2219-2654-2019-50-3-3-196-207

Стаття присвячена вивченню особливостей становлення професійної ідентичності в умовах змін. Дослідження проблеми ідентичності має декілька методологічних підходів: системний, феноменологічний, синергетичний. Виявлено сочіально-психологічні складові, які сприяють формуванню професійної ідентичності в складних ситуаціях невизначеності та визначено детермінанти, які заважають досягненню професійної ідентичності в умовах змін. Доведено потреба вивчення суб'єктивного фактору сприйняття змін особистістю та його вплив на формування професійної ідентичності. Важливою особливістю становлення професійної ідентичності в умовах змін $є$ включення минулих професійних та особистісних самовизначень, які вже реалізувалися та майбутніх виборів, щุо прогнозуються особистістю в нових обставинах буття. Виявлено рівні формування професійної ідентичності залежно від складності умов формування «Я» та способу функціонування психічного апарату людини. Доведено необхідність психологічної підтримки та психологічного супроводу становлення професійної ідентичності в кризові періоди змін, щзо сприяє розвитку позитивного емоиійного ставлення до професійного майбутнього ци розглядається як емоційний ресурс $i$ фактор конструктивного виходу з професійної кризи та успішного самовизначення.

Ефективність формування професійної ідентичності залежить від наявності наступних процесів: суб'єктивна визначеність особистості та суб'єктивне позитивне ставлення до професії; усвідомлення онтологічного та екзистенційного смислу професійного майбутнього; сформованість иілісного «Я», щзо встановлює індивідуальну професійну траєкторію на основі 
самопроектування, самопрогнозування та рефлексї суб'єктивного образу професійного «Я».

Змістовна наповненість професійнӧ̈ ідентичності містить якісні характеристики професійної діяльності, професійного спілкування та особливості особистості фахівцяя. Функцііональна складова професійної ідентичності визначається рівнем усвідомлення себе як професіонала, здатністю визначити власні професійні ресурси й можливості, передбачити перспективи професійного, кар'єрного зростання, вміння самопрезентувати себе як фахівия та здійснювати самопрогнозування професійної діяльності. Дослідження виявило, щзо фрормування професійної ідентичності носить інтегративний характер і багато в чому залежить від психологічних чинників: особистісних чинників; соціальних чинників, щуо сприяє ефективності супроводу становлення професійної ідентичності.

Ключові слова: ідентичність, професійна ідентичність, психологічний супровід, умови змін, самовизначення.

Постановка проблеми. Дослідження проблеми професійної ідентичності завжди набуває актуальності в умовах змін, де людина опиняється перед вибором, який вимагає самовизначення, самоорганізації та персоналізації. Це потребує від особистості розуміння власного «Я», визначення своїх сильних та слабких властивостей та можливостей. Невизначеність, яка супроводжує процеси змін, з точки зору соціологів, культурологів, складає сам «дух епохи постмодерну» $з$ їі деструктивними ідеалами, міфологемами, маніпулятивними медіа технологіями та ідеями «деконструкції». При цьому стан особистості характеризується як «безсилля, неспроможність, хаотичні дії та терор повної свободи - симптоми постмодерністської хвороби, що ранить особистість в i спробах «набуття власного обличчя» (3. Бауман, 2002). Водночас, ситуація змін - це ситуація зміни фактичних і гіпотетичних структур, ідентичності людини, «зміни якості іiі присутності в полі нездійснених можливостей» (Виготський, 1982). 
В професійній сфері людина стикається 3 різними контекстами застосування знань, необхідністю діяти та приймати рішення у короткий час, що посилює стан напруження, збільшує адаптаційний період та потребує використання комплексного підходу вирішення професійних завдань. У зв’язку 3 цим, важливим питанням $є$ створення умов, пошук адекватних засобів для формування професійної самосвідомості та професійної ідентичності.

Аналіз останніх досліджень і публікацій. Поняття «ідентичність», яке виявляє сутність «Я» особистості, вперше зустрічається у Сократа у вигляді: «пізнай себе». У філософській практиці ідею ідентичності знаходимо в наукових творах філософів різних епох: від античності (Аристотель, Платон) до вчених різних наукових традицій XIX - XXI століття - екзистенціалізму, феноменології, герменевтики (Гайдеггер, Гуссерль, Ясперс). У складному світі буття особистість потребує систему цінностей, професійно-життєвих орієнтацій, світоглядних спрямувань для відчуття цілісності, ототожнення себе 3 загальноприйнятим зразком. Але в становлення ідентичності в ситуації змін означає й досвід вибору, самовизначення, що грунтується на знання про «відповідність смислів часу».

Проблема ідентичності не нова та має декілька методологічних підходів (Шнейдер, 2001): 1. Системний підхід - дозволяє осягнути цілісність і складність психіки через знаходження смислів, сутностей і динамічних зв'язків. Тому основною складовою процесу становлення ідентичності $\epsilon$ пошук онтологічного й екзистенційного сенсу життя, результатом цих процесів $\epsilon$ життєвий вибір людини. 2. Феноменологічний підхід - зумовлює розуміння інтенцій суб'єкта, осягнення істини через знаходження правильних і точних слів, що $\epsilon$ результатом неусвідомленого прагнення до цілісності. 3. Синергетичний підхід - надає можливість досліджувати проблему ідентичності за допомогою міждисциплінарного напряму: від еволюційного до соціокультурного контексту.

Поняття «ідентичності» в психологічні науці пов'язується 3 проблемами цілісності: цілісність буття (Гайдеггер, К'еркегор) цілісність особистості 
(Максименко, 2010); цілісність підходу до вивчення особистості (Завацька, 2017); індивідуальна траєкторія розвитку особистості (Лушин, 2018). Вивчення проблеми ідентичності пов'язується з особливостями соціалізації особистості (Еріксон, 1996) й розглядають як багатомірний, інтегративний психологічний феномен, який реалізується в просторі самовизначення та самоорганізації життя особистості (Шнейдер, 2001).

Проблематика професійної ідентичності в умовах змін потребує вивчення суб'єктивного фактору сприйняття змін особистістю (Соколова, 2016) та можливі реакції на невизначеність залежно від особливостей особистості, які впливають на життєву та професійну сфери. Авторка виокремлює п’ять типів особистостей, залежно від суб'єктивних реакцій та переживань невизначеності у ситуаціях змін:

Перший тип - характеризується всепоглинаючим негативним афектом, нестерпною персекуторною тривогою. Суб'єктивна невизначеність максимальна: неясність, розмитість, безформність, безмежність, незв'язність викликають до життя паранояльні фантазійні репрезентації чужості, ворожості, що загрожує психологічному виживанню й цілісності «Я».

Другий тип - проявляє негативний спектр емоційних станів, двозначність, амбівалентність, багатозначність, непередбачуваність, суперечливість, заплутаність, складність. Страх новизни веде до спрощення, впорядкованості, рутинності, обмеженості та передбачуваності, що є захистом від очікуваної катастрофічності нового, переживання шоку, розгубленості, агорофобіі й паніки перед обличчям втрати (само) контролю та сталості «Я».

Третій тип - виявляє повну непереносимість невизначеності, як ситуації відсутності доступу до внутрішніх ресурсів; залежність від соціального оточення; відмову від власної системи еталонів й перевагу соціального конформізму; повну підпорядкованість авторитету, режиму, владі; нівелювання власного «Я», злиття з ситуацією.

Четвертий тип переживань невизначеності - маніакальна проекція «сп'яніння» від трансгресії і хаоса, відсутність всіляких кордонів, будь-яких 
стримувальних нормативів і правил, перевага вседоступності та вседозволеності.

П'ятий тип - розкриває переживання, які пов'язані 3 позитивним емоційним тоном: цікавість, пошукова надситуативна активність, гра фантазії, породження нових смислів, радість, азарт, пов'язані із задоволенням від досліджень та інсайтів, творче осмислення й перетворення ситуації невизначеності.

Таким чином, певний тип переживання особистістю невизначеності накладає відбиток на професійну сферу, усвідомлення нових можливостей, розширення репертуару професійних завдань або спрощення та збіднення власної професійної діяльності, що впливає на процес формування професійної ідентичності в умовах змін, зокрема призводить до формування дифузної ідентичності особистості.

Серед критеріїв ефективності становлення професійної ідентичності найважливішим визначається рівень сформованості антиципаційної компетентністі (Мельнік, 2013), яка складається 3 компонентів: 1) спрямованість часової децентрації; 2) емоційна налаштованість на своє майбутнє; 3) часова орієнтаціята рефлексія відношення до часу та майбутньої діяльності; 4) осмисленість життя, відчуття відповідальності за рішення, що приймаються. Особливої актуальності розвиток антиципаційної компетентності набуває саме в умовах змін, адже сприяє збагаченню індивідуального досвіду завдяки інтеграції минулого професійного досвіду 3 професійними перспективами в нових умовах й усвідомленню власних ресурсів, можливостей та обмежень.

Таким чином, для покращення процесу становлення професійної ідентичності особистості в умовах змін необхідно вивчення та створення оптимальних умов, застосування засобів психологічного супроводу формування професійної ідентичності особистості в сучасному суспільстві. 
Метою цієї статті є визначення особливостей психологічного супроводу формування професійної ідентичності в умовах змін на основі проведення порівняльного аналізу різних методологічних підходів.

Відповідно до зазначеної мети у статті поставлено завдання: розкрити основні акценти щодо психологічного супроводу становлення професійної ідентичності в умовах змін.

Для вирішення поставленої мети використано теоретичні методи наукового дослідження: аналіз та порівняння досліджуваної проблеми, вивчення та узагальнення основних підходів щодо проблеми ідентичності особистості, методи теоретичного узагальнення, які сприяли визначенню основних умов та чинників ефективного психологічного супроводу становлення професійної ідентичності в умовах змін.

Виклад основного матеріалу дослідження. Важливою особливістю становлення професійної ідентичності в умовах змін $є$ включення минулих професійних та особистісних самовизначень, які вже реалізувалися та майбутніх виборів, які прогнозуються особистістю в нових обставинах буття (Л. Шнейдер).

Проблематика формування професійної ідентичності може розглядатися на декількох рівнях залежно від складності умов формування «Я» та способу функціонування психічного апарату людини (Русійон, 2015). Це спонукає розглянути становлення професійної ідентичності в «контексті логіки», у відповідності з якою функціонує психіка людини в умовах змін. Виокремимо різні принципи функціонування та типи логіки.

Перший принцип функціонування психіки або перша логіка («логіка Всього») - це перша модель, яка домінує в ранньому дитинстві, коли немовля отримує все й відразу, це те, що 3. Фройд називав «океанічним почуттям» (в роботі «Майбутнє однієї ілюзії», 1927p). Ця логіка ніколи повністю не зникає, вона зустрічається й в іншому віці, зокрема в умовах змін, в кризові періоди дорослих людей, у яких в дитинстві не було можливості отримати цей ранній досвід «всього і відразу». Без наявності такого досвіду з'являється внутрішній 
примус, що не дозволяє розслабитися, змушує людину завжди знаходитися у пошуках, бути в русі, завжди намагатися щось знайти, досягти, зробити. Так, причиною гіперактивності дітей і дорослих часто є те, що «логіка Всього» в ранньому дитинстві не була здійснена.

Логіку «всього» часто доповнюють «все або нічого», «все й негайно», що вказує на контрастний спосіб функціонування людини, тобто, якщо «немає всього - значить, немає нічого». Тому часто така поведінка призводить до руйнування та тоталітаризму. Отже, перша модель - це пошук ідентичності перцепції, або сприйняття, при якому все має реалізуватися, повністю відповідати й збігатися відповідно до уявлень та бажання особистості. В контексті теми дослідження, людині з такою логікою досягти рівня професійної ідентичності складно, навіть, в стабільних умовах, а в періоди швидких змін у людини повністю або частково руйнуються уявлення про професію та місце людини в ній. Це може призвести до стану безпомічності, деструктивних, депресивних, паранояльних проявів у поведінці.

Другий спосіб функціонування й друга логіка «не-все» - можливо все, але не негайно, не «я сам», не все разом, не все до кінця, не без зусиль, але символічно можливе отримання всього. Отже, у другому способі функціонування людина починає знаходити місце для процесу диференціації і символізації. Другий спосіб - це пошук ідентичності мислення, яке не потребує точної копії предмету бажання, достатньо того, щоб предмет був подібний. Ці два способи функціонування перетинаються, не існують окремо, проте один 3 двох завжди домінує. Таким чином, людина формує власну професійну ідентичність, яка відповідає загальним вимогам професії, але не потребує тотальності у досягненні професійної ідентичності.

Третій спосіб функціонування - «логіка Вибору»: дочекатися вдалого моменту й слушного часу, обрати оптимальний предмет i способи дії, створювати у сприятливих обставинах з відповідними людьми. Таким чином, людина не тільки здатна символізувати, але й робити вибір, розвивати життя, розвиватися у професії, володіти здатністю задовольняти свої бажання 
відповідно до певних умов, в яких опинилася. Тому за С. К'єркегором, перед людиною стоїть не питання вибору - «або-або», а питання об'єднання «і-і». Визнання обмежень, законів і необхідності перешкоджає тому, щоб полинути в нескінченне і лише «борсатися в можливому».

Ситуації змін призводить до невизначеності, водночас вимагає вибору та самовизначення у найважливіших сферах буття людини: особистісної, соціальної комунікації і взаємодії, професійної діяльності. Цікавими $є$ дослідження Д. Леонтьєва щодо психології вибору в ситуації змін, зокрема вивчення впливу на вибір особистісних змінних, задоволеності виборами, якості сприйняття вибору тощо. Автор виокремлює: а) повсякденні вибори, які визначаються особистісними змінними, тобто особистість проявляє себе через повсякденні вибори; б) доленосні вибори, які не корелюють з особливостями особистості, винятком $є$ - здатність до толерантності до невизначеності, що свідчить про досягнення індивідуальної зрілості, константності й цілісності «Я», здатного справлятися з тривогами. Проте, саме в доленосних виборах відбувається трансформація особистості - «особистість оновлюється» (С. К'єркегор). Тому можемо вважати, що усвідомлений вибір професії або іiі зміна, як доленосний вибір призводять до самовизначення особистості, відповідальності за свій вибір, професійної комунікації у спільноті, що сприяє формуванню певного типу мислення, світогляду та професійної ідентичності. Але в умовах постійних змін цей процес ускладнюється, що може спричинити формування дифузної ідентичності особистості.

Формування професійної ідентичності в кризові періоди, періоди змін потребують психологічної підтримки, адже психологічний стан людини часто супроводжується різними емоційними переживаннями, важкими обставинами, розв'язання яких є основою для змін: 1) зміна загального психоемоційного стану (пригнічення, депресія; тривожність; невпевненість; невмотивоване почуття занепокоєння); 2) зміна емоційно-вольової сфери (нестриманість, замкнутість; дратівливість; прояви агресії, конфліктність); 3) соматичні прояви (погіршення загального самопочуття; загострення й виникнення захворювань); 
4) зміна світогляду (тривалі роздуми про життя, його якості; критична оцінка своїх досягнень; 5) переосмислення свого місця, призначення та картини світу; бажання або страх перед змінами); 6) зміни в мотиваційній сфері (переоцінка цінностей, перевірка мотивів діяльності, критичний аналіз стосунків 3 іншими; розрив або зміна партнера, розлучення; аналіз професійних досягнень; зміна професійної діяльності; зниження професійної активності). Позитивне емоційне ставлення до професійного майбутнього може розглядатися як емоційний ресурс і фактор конструктивного виходу з професійної кризи та успішного самовизначення.

Професійну ідентичність варто розглядати як інтегративне поняття, в якому можна виокремити змістовні й функціональні складові (Мельнік, 2011). Змістовна наповненість професійної ідентичності містить якісні характеристики професійної діяльності, професійного спілкування та особливості особистості фахівця. Для реалізації змістовної складової професійної ідентичності необхідно враховувати: 1) організацію професійного досвіду; ресурси та можливості професійного розвитку, усвідомлення обмежень у професійній сфері, створення професійного образу «Я»; 2) організацію взаємодії, професійної комунікації, підтримки в професійній спільноті; 3) розвиток цілісності професійного Я, особистісних якостей фахівця.

Функціональна складова професійної ідентичності визначається рівнем усвідомлення себе як професіонала, здатністю визначити власні професійні ресурси й можливості, передбачити перспективи професійного, кар'єрного зростання, вміння самопрезентувати себе як фахівця та здійснювати само прогнозування професійної діяльності. Важливого значення в цих процесах набуває антиципація та корекція професійних планів і перспектив.

Ефективність формування професійної ідентичності залежить від наявності наступних процесів:

- суб'єктивна визначеність особистості в контексті життєвого й професійного часу та перспектив; 
- усвідомлення онтологічного та екзистенційного смислу професійного майбутнього;

- сформованість цілісного «Я», що встановлює індивідуальну професійну траєкторію на основі самопроектування, самопрогнозування та рефлексії суб'єктивного образу професійного «Я».

Враховуючи «інтегративний характер» професійної ідентичності, можна виокремити наступні кроки у наданні психологічного супроводу:

Таблиця 1

\section{Психологічний супровід процесу становлення професійної} ідентичності

\begin{tabular}{|c|c|}
\hline $3 \mathrm{Mi}$ & \\
\hline $\begin{array}{l}\text { 1. Якісні характеристики } \\
\text { професійної діяльності: організація } \\
\text { професійного досвіду. } \\
2 . \text { Особливості професійного } \\
\text { спілкування: організація взаємодії, } \\
\text { спілкування, підтримки в професійній } \\
\text { спільноті. } \\
3 . \quad \text { Особливості особистості } \\
\text { фахівця: розвиток цілісності } \\
\text { професійного «Я», особистісних } \\
\text { якостей фахівця (етика, резилієнс, } \\
\text { суб'єктивне ставлення до професії } \\
\text { тощо). } \\
4 . \quad \text { Професійний } \\
\text { інформаційно-наповнений, безпечний } \\
\text { психологічний простір. }\end{array}$ & $\begin{array}{l}\text { 1. Рефлексія й усвідомлення } \\
\text { себе як фахівця. } \\
2 . \text { Визначення професійних } \\
\text { можливостей, ресурсів, перспектив, } \\
\text { самопрогнозування професійного } \\
\text { зростання. } \\
\text { 3. Антиципація професійних } \\
\text { спрямувань та мобільна, гнучка } \\
\text { система професійного й життєвого } \\
\text { коригування особистісно-професійних } \\
\text { перспектив. } \\
4 \text { Наратив, як безпечне } \\
\text { психологічне місце. }\end{array}$ \\
\hline
\end{tabular}


Періоди змін часто приводять до кризи, що впливає на всі екзистенційні виміри та фундаментальні мотивації особистості, які зазнають руйнівного впливу. В результаті невідповідності, напруження або жаху, пережитих людиною, блокується процесуальна здатність «Я» до опрацювання та інтеграції отриманих вражень. Тому для забезпечення умов формування професійної ідентичності в період криз пропонуємо наступне:

- супровід від пасивного буття до активного формування власної екзистенції;

- визначити та усвідомити життєву задачу - криза, як завдання може мати свій сенс;

- побачити більш широкий контекст (онтологічний сенс) та індивідуальний (екзистенційний сенс);

- розуміння руху життя, більш широких перспектив та досягнень;

- формулювання відновлення плану, цілей, ресурсів.

Для дослідження професійної ідентичності було обрано наступні методики: методика «Дослідження статусів професійної ідентичності» (А. Азбель, Л. Шнейдер); тест Дж. Голланда на визначення професійної спрямованості особистості; методика дослідження рефлексивності (А. Карпов); тест опитувальник «Тест смисложиттєвих орієнтацій» (Д. Леонтьєв); методика «Особистий професійний план» (Є. Клімов в адаптації Л. Шнейдер); методика діагностики рівня емпатійних здібностей (В. Бойко). За результатами дослідження визначено особистісні риси, які сприяють формуванню статусу «досягнена ідентичність»: здатність до рефлексії (зокрема до професійної рефлексії), здатність до самопізнання й саморозуміння, уміння ставити цілі, адекватні потребам, уміння досягати, здійснювати вольовий акт, активне прагнення до усвідомленості та керованості життям, розвинута толерантність до невизначеності.

Висновки. Дослідження виявило, що важливу роль для формування професійної ідентичності має мотиваційна складова, а також зрілість інтересів. Формування професійної ідентичності має інтегративний характер і багато в 
чому залежить від: 1) психологічних чинників: рівень та структура інтелекту, відповідний спосіб мислення, здатність відновлюватися в умовах криз; 2) особистісних чинників: особливості особистісного розвитку; індивідуальна швидкість особистісного зростання, зрілість особистості, як здатність робити вибір; 3) соціальних чинників: супровід процесу становлення професійної ідентичності, якості освітніх програм, наявності соціально-психологічної підтримки та допомоги в ситуації змін; можливість допомагати іншим.

Знання цих чинників, визначення їх ролі у становленні професійної ідентичності дозволить розробити та реалізувати корекційно-розвивальні програми психологічної підтримки процесу формування професійної ідентичності в умовах змін.

\section{Література}

1. Бауман 3. Индивидуализированное общество. М.: Логос, 2002. 390 с.

2. Василюк Ф.Е. Психология переживания: анализ преодоления критических ситуацій. М.: МГУ, 1984. 200 с.

3. Гришина Н. В. Психология социальных ситуацій. Психология социальных ситуаций: хрестоматия. СПб.: АСТ, 2001. С. 19-23.

4. Гуревич П. С. Проблема идентичности человека в философской антропологии. [Электронный ресурс]. Доступно: https://iphras.ru/uplfile/root/biblio/vst/2010/04.pdf

5. Левченко В. В. Особистісна ідентичність у процесі адаптації в ситуації життєвих змін. Духовність особистості: методологія, теорія $і$ практика: збірник наукових праџь. 2016. Вип. 1 (70). С. 78-86.

6. Малахов В. С. Неудобства с идентичностью. Вопросы философии. 1998. №2. C.43-53.

7. Мельнік Н. Ю. Антиципаційна компетентність як фактор становлення професійної ідентичності. Проблеми сучасної психологї. 2013. Вип. 20. С. 385 395. 
8. Шнейдер Л. Б. Профессиональная идентичность: монография. М.: МОСУ, 2001. $272 \mathrm{c}$.

9. Ериксон Е. Иденичность, юность и кризис. М.: Знание, 1996. 634 с.

10. Baumeister R. Identity. Cultural Change and Struggle for Self. N. Y., Oxford, 1986.

11. Roussillon. An introduction to the work on primary symbolization. Int $\mathbf{J}$ Psychoanal (2015) 96:583-594.

\section{References}

1. Bauman Z. Yndyvydualyzyrovannoe obshchestvo [An individualized society]. M.: Lohos, 2002. 390 s. [in Russian].

2. Vasylyuk F. E. Psykholohyya perezhyvany ya: analyz preodolenyya krytycheskykh sytuatsiy [Psychology of experience: analysis of overcoming critical situations]. M.: MHU, 1984. 200 s. [in Russian].

3. Hryshyna N. V. Psykholohyya sotsyal'nykh sytuatsiy [Psychology of social situations]. Psykholohyya sotsyal'nykh sytuatsyy: khrestomatyya. St. Petersburg: AST, 2001. S. 19-23 [in Russian].

4. Hurevych P. S. Problema ydentychnosty cheloveka v fylosofskoy antropolohyy [The Problem of Human Identity in Philosophical Anthropology]. [Élektronnyy resurs]. Dostupno: https://iphras.ru/uplfile/root/biblio/vst/2010/04.pdf [in Russian].

5. Levchenko V. V. Osobystisna identychnist' u protsesi adaptatsiyi v sytuatsiyi zhyttyevykh zmin [Personal identity in the process of adaptation in the situation of life changes]. Dukhovnist' osobystosti: metodolohiya, teoriya i praktyka: zbirnyk naukovykh prats'. 2016. Vyp. 1 (70). S. 78-86 [in Ukrainian].

6. Malakhov V. S. Neudobstva s ydentychnost'yu [Discomforts with identity]. Voprosy fylosofyy. 1998. №2. S.43-53 [in Ukrainian].

7. Mel'nik N. YU. Antytsypatsiyna kompetentnist' yak faktor stanovlennya profesiynoyi identychnosti [Antitrust competence as a factor of professional identity formation]. Problemy suchasnoyi psykholohiyi. 2013. Vyp. 20. S. 385-395 [in Ukrainian]. 
8. Shneyder L. B. Professyonal'naya ydentychnost': monohrafyya [Professional identity: a monograph]. M.: MOSU, 2001.272 s.

9. Erykson E. Ydenychnost', yunost' y kryzys [Identity, youth and crisis]. M.: Znanye, 1996. $634 \mathrm{~s}$.

10. Baumeister R. Identity. Cultural Change and Struggle for Self. N. Y., Oxford, 1986.

11. Roussillon. An introduction to the work on primary symbolization. Int $\mathbf{J}$ Psychoanal (2015) 96:583-594.

Levchenko Viktoriia

\section{PSYCHOLOGICAL SUPPORT OF FORMATION OF PROFESSIONAL IDENTITY IN THE CHANGES OF CHANGE}

ORCID iD: https://orsid.org/0000-0003-4691-9445

The article is devoted to the study of the peculiarities of becoming a professional identity in the face of change. Identity problem research has several methodological approaches: systemic, phenomenological, synergistic. An important feature of becoming a professional identity in the face of change is the incorporation of past professional and personal self-determinations that have already taken place and future choices that a person predicts in new circumstances of being. The levels of formation of professional identity are revealed depending on the complexity of the conditions of formation of "I" and the way of functioning of the mental apparatus of the person. The necessity of psychological support and psychological support for the development of professional identity during the crisis periods of change has been proved, which promotes the development of a positive emotional attitude to the professional future and is considered as an emotional resource and a factor of constructive exit from the professional crisis and successful self-determination.

The effectiveness of professional identity formation depends on the presence of the following processes: subjective personality and subjective positive attitude to the profession; awareness of the ontological and existential meaning of a professional 
future; the formation of an integral "I" that establishes an individual professional trajectory based on self-projection, self-forecasting and reflection of the subjective image of the professional "I".

The rich content of professional identity contains qualitative characteristics of professional activity, professional communication and personality of a specialist. The functional component of professional identity is determined by the level of awareness of oneself as a professional, the ability to identify their own professional resources and opportunities, to anticipate prospects for professional, career growth, the ability to self-present themselves as a specialist and to carry out self-forecasting of professional activity.

Keywords: identity, professional identity, psychological support, conditions of change, self-determination.

\section{Інформація про автора}

Левченко Вікторія Володимирівна, доцент кафедри філософії і освіти дорослих ДЗВО «Університет менеджменту освіти» Центральний інститут післядипломної освіти, доцент, кандидат філософських наук, м. Київ.

Levchenko Viktoriia Volodymyrivna, Associate Professor, Department of Philosophy and Education of Adults, State Higher Educational Institution «University of Educational Management» National Academy of Educational Sciences of Ukraine Central Institute of Postgraduate Education, Associate Professor, Phd in Philosophy, Kyiv. 